

\section{Green Pricing Program Marketing Expenditures: Finding the Right Balance}

\author{
Barry Friedman and Mackay Miller
}

Prepared under Task No. SA09.3003
Technical Report NREL/TP-6A2-46449

September 2009

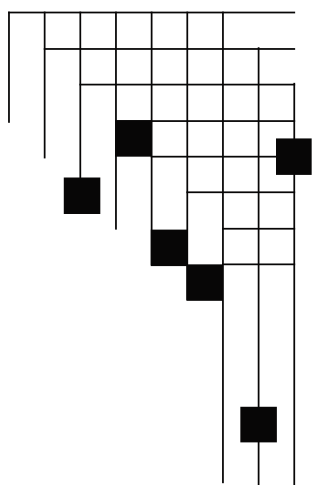




\section{NOTICE}

This report was prepared as an account of work sponsored by an agency of the United States government. Neither the United States government nor any agency thereof, nor any of their employees, makes any warranty, express or implied, or assumes any legal liability or responsibility for the accuracy, completeness, or usefulness of any information, apparatus, product, or process disclosed, or represents that its use would not infringe privately owned rights. Reference herein to any specific commercial product, process, or service by trade name, trademark, manufacturer, or otherwise does not necessarily constitute or imply its endorsement, recommendation, or favoring by the United States government or any agency thereof. The views and opinions of authors expressed herein do not necessarily state or reflect those of the United States government or any agency thereof.

Available electronically at http://www.osti.gov/bridge

Available for a processing fee to U.S. Department of Energy and its contractors, in paper, from:

U.S. Department of Energy

Office of Scientific and Technical Information

P.O. Box 62

Oak Ridge, TN 37831-0062

phone: 865.576 .8401

fax: 865.576 .5728

email: mailto:reports@adonis.osti.gov

Available for sale to the public, in paper, from:

U.S. Department of Commerce

National Technical Information Service

5285 Port Royal Road

Springfield, VA 22161

phone: 800.553 .6847

fax: 703.605.6900

email: orders@ntis.fedworld.gov

online ordering: http://www.ntis.gov/ordering.htm 


\section{Acknowledgments}

This work was funded by the U.S. Department of Energy's (DOE) Office of Energy Efficiency and Renewable Energy (EERE). The authors wish to thank Linda Silverman and the EERE technology programs for their support and review of this work. The authors also wish to thank Lori Bird, Lynn Billman, and Claire Kreycik of NREL; Adam Capage, Gabe Petlin, and Amanda Mortlock of 3Degrees Inc.; Jay Carlis of Community Energy Inc.; Blaine Collison of the U.S. Environmental Protection Agency; Rob Harmon of the Bonneville Environmental Foundation; Alex Pennock of the Center for Resource Solutions; Dan Drennan of PNM Resources; Edward Holt of Ed Holt \& Associates; John Holtz of Green Mountain Energy Company; Susan Innis of the Colorado Governor's Energy Office; Pat Keily of We Energies; Rita Kilpatrick of the Southern Alliance for Clean Energy; Lisa Schwartz of the Regulatory Assistance Project; Laura Bickel of the Massachusetts Department of Public Utilities; and David Wright of the Ecology Center for their thoughtful review of the document, as well as Paula Pitchford of NREL for her editorial support. Additional information on green power market trends and activities can be found on DOE's Green Power Network Web site at http://greenpower.energy.gov. 


\section{List of Acronyms}

$\begin{array}{ll}\text { CAC } & \text { customer acquisition cost } \\ \text { FPL } & \text { Florida Power \& Light } \\ \text { FPSC } & \text { Florida Public Service Commission } \\ \text { GME } & \text { Green Mountain Energy Company } \\ \text { GP } & \text { green pricing } \\ \text { kWh } & \text { kilowatt-hour } \\ \text { M\&A } & \text { marketing and administration } \\ \text { MW } & \text { megawatt } \\ \text { MWh } & \text { megawatt-hour } \\ \text { NREL } & \text { National Renewable Energy Laboratory } \\ \text { PPA } & \text { power purchase agreement } \\ \text { PUC } & \text { Public Utility Commission } \\ \text { PV } & \text { photovoltaic } \\ \text { RE } & \text { renewable energy } \\ \text { REC } & \text { renewable energy certificate } \\ \text { RPS } & \text { renewable portfolio standard } \\ \text { VGP } & \text { Vectren Green Power }\end{array}$




\section{Executive Summary}

Voluntary utility-based green pricing programs in the United States have grown significantly in the past five years, from 1.8 billion $\mathrm{kWh}$ in sales in 2004 to more than 4.8 billion $\mathrm{kWh}$ in sales for 2008. However, program growth slowed in 2008 compared to that of previous years.

Yet, in July 2008, when the Florida Public Service Commission (FPSC) voted to terminate Florida Power \& Light's (FPL's) Sunshine Energy green power program, some industry stakeholders and members of the media raised questions about whether other green pricing programs were spending too much on marketing. Although the Sunshine Energy termination was based on the FPSC's questioning of the need for a voluntary program in light of Florida's expected renewable portfolio standard (RPS), the termination sparked a debate that went beyond the issues in the FPL case, focusing on whether PUCs and consumer watchdogs were requiring - or programs were providing - sufficient transparency to serve consumer protection interests. Often, program participants may be unaware of what projects they are supporting with their dollars, particularly for those programs sourced through renewable energy certificates from non-local sources.

In practice, it is difficult to determine the optimal amount to spend on marketing and administering a green pricing program. Budgets for marketing and administration of green pricing programs are a function of several factors: the region of the country; the size of the utility service area; the customer base and media markets encompassed within that service area; the point or stage in the lifespan of the program; and certainly, not least, the utility's commitment to and goals for the program. All of these factors vary significantly among programs.

In addition, views about an appropriate level of expenditure on marketing often rest on whether it is framed as consumer education in the public interest. Programs must balance investing in consumer education, expanding program participation, keeping participation affordable, and ensuring that sufficient portions of premiums are spent on new renewable energy development, what might be thought of as "product quality." Although a program might want to emphasize one over the other, the two goals are not mutually exclusive; strong marketing has been shown to support robust participation, which can enable a program to support new renewable energy projects. The design of a program strategy depends on what the strategy is meant to accomplish. Some utilities have comprehensive environmental goals or goals intended to green their brand. Others are satisfied by merely making the program available to customers.

The question of an appropriate amount of marketing expenditures has arisen within a context of product quality and program integrity. Specifically, there is a perception that participants' dollars could be put to better use through greater investments in new renewable capacity than in marketing.

This report presents data on programs that have funded both marketing and program administration. The National Renewable Energy Laboratory (NREL) gathers the data annually from utility green pricing program managers. Programs reporting data to NREL spent a median of $18.8 \%$ of program revenues on marketing their programs in 2008 and $16.6 \%$ in 2007 . The smallest utilities (those with less than 25,000 in their eligible customer base) spent $49 \%$ of 
revenues on marketing, significantly more than the overall median. Data reported from utilities yields a median estimated customer acquisition cost of $\$ 27$ per net new residential customer in 2008 , compared to a median customer acquisition cost of $\$ 30$ in $2007 .{ }^{1}$ These numbers should be viewed as indicative; particularly after programs reach beyond the "low hanging fruit" of customers most likely to participate, it can be significantly more expensive to attract customers.

Following the termination of the FPL program, some U.S. public utility commissions (PUCs) made inquiries concerning the way programs spend customer premiums, whether they spend too much on marketing at the expense of products, and the value customers receive for the premiums they pay to participate. This report addresses the role of renewable energy credit (REC) marketers and start-up costs - and the role of marketing, generally, in achieving program objectives, including expansion of renewable energy. We also address the following related questions:

- Does the voluntary market support new, additional renewable development?

- Are program marketing efforts benefiting the public interest, or just supporting private gain?

- What are some of the costs and risks incurred by REC marketers operating in partnership with green pricing programs?

- Is it feasible, and would it be beneficial, for green pricing programs to be more transparent in either regulatory or public disclosure, with regard to projects supported and/or program expenditures?

Framing these questions in the form of common criticisms recently expressed in the market and the media, this report aims to shed light on considerations that should be included in analyzing these issues and to support policy-makers, regulators, and the public in assessing green power program budgetary choices and the related issues of market transparency and integrity.

${ }^{1}$ Of 84 respondents to the survey, 48 green power programs provided adequate data to estimate the CAC. 


\section{Table of Contents}

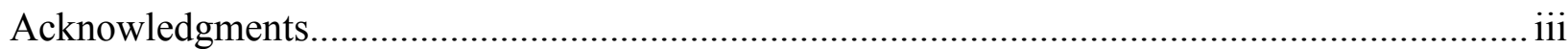

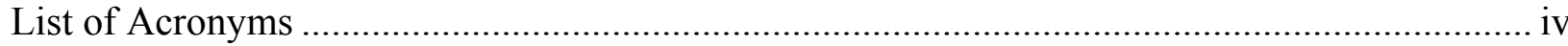

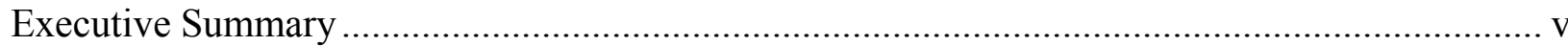

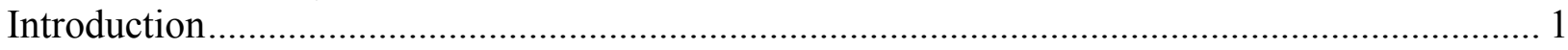

Green Pricing Program Marketing and Administration Expenditure Data................................ 4

Common Criticisms ........................................................................................................ 7

Common Criticism No. 1: Green Pricing Programs Spend too Much on Marketing .................. 7

Common Criticism No. 2: Marketing Expenditures Serve Private, not Public, Interests......... 17

Common Criticism No. 3: Green Pricing Programs do not Result in New RE Development . 19

Common Criticism No. 4: Programs are not Sufficiently Transparent ..................................... 22

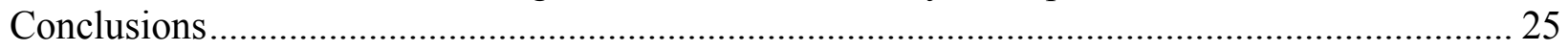

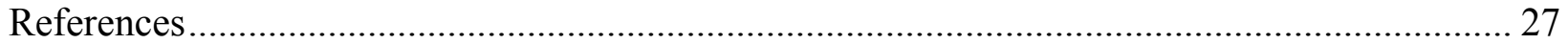

Appendix. Sample Green Pricing Program Marketing Materials .................................................. 29

\section{List of Figures}

Figure 1. Average Marketing and Administrative Expenses (gross) in 2008, by Size of Eligible Customer Base.

Figure 2. Median Marketing and Administrative Expenses in 2008 as a Percentage of Green Power Revenue.......................................................................................................... 5

Figure 3. 2008 Average Marketing Expenditure (cents) per kWh of Green Power Sold, by Size of Utility.

Figure 4. Utility Expenditures on Marketing, Total Number of Utilities Providing Data to NREL,

Compared with Top Performing Utilities Providing Data for 2006 ........................................ 9

Figure 5. Average Dropout Rate in Voluntary Green Power Programs, 2003-2008 ..................... 13

Figure 6. Mean Annual Marketing Expenditure, Years 1-3 ………………………………........ 14

Figure 7. 2008 Customer Acquisition Cost, by Customer Base Size …………………………..... 16

Figure 8. Example of Green Pricing Messaging ...................................................................... 20

Figure A-1. A Portion of a Sample Marketing Piece from the Pacific Power Green Pricing

Program ................................................................................................................ 29

Figure A-2. A Portion of a Sample Marketing Piece from the Sacramento Municipal Utility

District Green Pricing Program......................................................................................... 30 


\section{Introduction}

Voluntary utility-based green pricing programs in the United States have grown significantly in the past five years, from 1.8 billion $\mathrm{kWh}$ in sales in 2004 to more than 4.8 billion $\mathrm{kWh}$ in sales for 2008. Although these long-term growth trends continued in 2008, growth rates for program sales showed a year-over-year decline among utility-based programs, for the first time in several years. In particular, the growth of residential participation in green pricing programs in regulated states slowed in 2008 (Bird et al. 2009). This recent pattern emerged against a complex backdrop that included a global economic crisis, a presidential campaign emphasizing renewable energy (RE), and a public dialogue more focused on clean energy solutions than at any other time in almost 30 years.

At the same time, public regulatory commissions and other voluntary green market stakeholders have begun to more closely scrutinize the marketing expenditures of green power programs. These concerns came to the fore in July 2008, when the Florida Public Service Commission (FPSC) voted to terminate Florida Power \& Light (FPL)'s Sunshine Energy green power program, the first time a sizable green pricing program was terminated by a regulatory body.

Initially, the reason the commission acted to terminate the Sunshine Energy program was an audit finding by the FPSC Audit Staff that only about $24 \%$ of the $\$ 11.3$ million collected from program participants was applied to developing renewable energy facilities and that the majority of the revenue was directed toward marketing and administrative costs. ${ }^{2}$ Even though a subsequent audit of the program resulted in a different set of conclusions and a different rationale for termination, the event became the impetus for a discussion among industry observers on the subjects raised initially in the case.

Because the Sunshine Energy program sparked the debate, it is important to understand the FPSC's final basis for the decision to terminate the program, a different set of issues that was instead related to their assessment of the need for a voluntary program in Florida after the legislature mandated an RPS:

Although the Program was improving in the last year or so in terms of contributions to renewable energy, the Program was terminated because it no longer served the interests of its participants and no longer aligned with current state renewable energy policies. With the recent legislation directing the FPSC to promulgate rules for a Renewable Portfolio Standard and a growing emphasis on developing renewable energy sources within the State, it is appropriate to critically reassess the use of "voluntary" customer contributions as a tool to promote renewable energy. ${ }^{3}$

\footnotetext{
${ }^{2}$ In the ruling, a secondary issue was that some Commissioners asserted that the program was no longer necessary because the state has recently adopted policies to encourage the development of renewable resources in the state. Order No. PSC-08-0600-PAA-EI, issued September 16, 2008, in Docket No. 070626-EI, the Commission terminated the program effective July 29, 2008 (FPSC 2008).

${ }^{3}$ FPSC Vote Sheet, Commission Memo: Request for Oral Modification - Item 10, September 29, 2008, Agenda Conference.
} 
The program was run primarily by a third-party renewable energy credit (REC) marketer, Green Mountain Energy Company (GME), in partnership with the utility. Among the FPSC's stated concerns at the time was that the program was charging its residential customers $\$ 9.75$ per month and paying about $\$ 2.75$ per month for the renewable energy to supply the program. ${ }^{4}$ However, a second audit by the FPSC Audit Staff found that approximately $41 \%$ of program revenues had been allocated for renewable energy supply for the program, which included a portion for "accrual...for future payments." 5

In a May 2008 order, the Indiana Utility Regulatory Commission similarly found that a voluntary program proposed by Southern Indiana Gas \& Electric Company, while "a laudable effort," was "apt to be confusing to its customers and ... not ... in the public interest," based on the contention that "customers are likely to believe they are purchasing renewable energy by enrolling in the VGP [sic] program, when in fact they are paying Vectren South to retire the RECs that are associated with the renewable energy they have already paid for in their electric bill ... with the proceeds going primarily to pay for VGP program administration costs."

These instances have amplified questions among market participants, consumer advocates, and regulators about the value customers are receiving for their premiums and how revenues from premiums are spent. From the point of view of some utility program administrators and of REC marketing companies partnering with utilities, there is a sense that their business model and the benefits of green pricing may be somewhat misunderstood and that a better sense of the context in which decisions are made would be useful to the industry.

In this, it may be helpful to better understand various considerations related to marketing expenditures. These include the costs and risks specific to a program's start-up phase, as well as those associated with long-term engagement in wholesale renewable energy markets, for which prices have fluctuated widely in the face of regulatory and supply-related uncertainties, as well as among U.S. regions. In addition, marketing expenditures are meant to satisfy goals and utility or public values that extend beyond sign-ups, such as public awareness and the value of customer education. Lastly, marketing costs across industries may also not be well understood. Financial services firms, for example, spend as much as $\$ 280$ to obtain a new residential customer (Wreden 2005).

In addition, the role of the voluntary market in U.S. renewable energy development has been significant (Bird et al. 2004, Bird et al. 2008). From 2004 to 2008, voluntary market demand for

\footnotetext{
${ }^{4}$ According to GME, that audit was conducted in May 2008 without the participation of GME or review of GME's financial records for the program. The terms of GME's contract for the Sunshine Energy program explicitly prevented GME from participating in state regulatory matters or communicating directly with the FPSC. Following the commission's vote to terminate the program, GME was free to communicate with the FPSC. The commission voted to terminate the program on July 29, 2008, but kept the docket open to facilitate further audit review of the program. GME subsequently volunteered to a comprehensive audit of its program records by FPSC Audit Staff at the company's headquarters in Austin, Texas.

${ }^{5}$ Division of Regulatory Compliance and Consumer Assistance Auditor's Report, September 3, 2008, FPSC Auditor Report, August 28, 2009, Table, p. 7. The Commission reviewed the additional audit findings at its session on September 29, 2008. In its vote sheet dated September 29, 2009, the commission voted to accept the audit findings and close the docket, the commission determined "the audit results indicate Green Mountain used the monies for purposes related to the Sunshine Energy Program."

${ }^{6}$ Order of the Indiana Utility Regulatory Commission, Cause \# 43259 Sl, May 28, 2008.
} 
renewables slightly exceeded compliance market demand for new renewables (Bird et al. 2009). ${ }^{7}$ In 2008, state RPS policies collectively called for utilities to procure about 23 billion $\mathrm{kWh}$ of "new" renewable energy generation (Barbose 2009), compared to about 24 billion kWh sold into the voluntary green power market. ${ }^{8}$ In addition, although the contention cannot be proven, the awareness raised through program marketing may well have increased the popularity or helped pave the political path toward RPS requirements, because several states-perhaps most notably California, New York, Wisconsin, Colorado, and Texas-had relatively successful voluntary programs before their RPS was either enacted or increased.

The question of the appropriateness of marketing expenditures is most often raised in the context of charitable organizations and other nonprofits, whose success is in fact sometimes rated or ranked on how little they spend on marketing and overhead. ${ }^{9}$ The question is asked far less of for-profit companies, and GME argued the applicability of the question in its defense before the FPSC, as follows:

[A] utility company might contract with a local General Motors dealer to purchase a fleet of trucks. The utility pays the dealer the agreed-upon price .... After the dealer has covered the cost of purchasing and delivering the trucks, any revenue left over from the purchase price belongs to the dealer. Any inquiry into the dealer's advertising, selling or other costs is inappropriate and demonstrates a misunderstanding of the legal and economic basis of the relationship between the dealer and FPL.

However, any utility program, whether or not partnered with a private company, could be expected to address the question of appropriate marketing expenditure levels, because regulators are charged with protecting the public interest in a way for which private industry has no analog.

The question of whether marketing expenditures are too high leads to an evaluation of several underlying issues. The concerns and debates that surround marketing expenditures have their roots across legal, business, environmental, and regulatory contexts. In this paper, we identify and analyze ancillary questions and cover the following aspects of the central question about appropriate or optimal marketing expenditures, such as whether a green power purchase is a product or charitable contribution, whether marketing is equivalent to consumer education about renewables, the degree to which new renewable development results from participation in a green pricing program, the importance of price transparency to regulators and of product transparency for consumers, and the role marketing expenditures play in start-up costs.

\footnotetext{
${ }^{7}$ For 2008 , sales by green pricing programs in regulated states grew by $12 \%$ and by $19 \%$ in restructured states, compared with growth rates of $25 \%$ and more than $88 \%$ respectively, for 2007 .

${ }^{8}$ While RPS policies generally allow pre-existing renewable energy generation sources (i.e., those installed prior to the adoption of the RPS) to meet their targets, the estimates presented here reflect only the amount of new renewable energy generation that these policies are expected to stimulate. New is defined by the Center for Resource Solutions as generated from a project that became operational on or after January 1, 1997. These figures are compared to the voluntary market estimates, because voluntary markets primarily support generation from new renewable energy projects (i.e., those installed after voluntary green power markets were established). Estimates of compliance market demand assume that RPS targets are fully met, which is not always the case.

${ }^{9}$ For example, www.guidestar.com ranks nonprofits on this basis. The comparison of green pricing programs to nonprofits is made for several reasons. Perhaps the most important for our purposes is the similarity in messaging. Similar to charitable organizations, green pricing programs typically craft cause-marketing messages that resemble a request for a donation in that an appeal is made to make a difference or do the right thing.
} 
The report aims to shed light on considerations that should be included in a complete analysis of these issues and improve the basis upon which decision makers, regulators, and the public can assess and improve green power program budgetary choices. In many cases, however, solutions to issues raised are within the purview of the marketplace, utility management, policy-makers, and regulators.

We present these topics in the context of the recent criticisms within which they have been raised. We also provide a brief discussion of tactics - the various mechanisms employed by programs to deliver their message and on which marketing dollars are spent. Finally, we provide in a sidebar, an illustration of some ways to measure marketing expenditures and the difficulties inherent in some metrics. We begin with what is known about how much programs actually spend on marketing and program administration. The data is somewhat sparse because of inconsistencies in program data tracking.

\section{Green Pricing Program Marketing and Administration Expenditure Data}

Annual data reported to NREL by green pricing program managers show a very wide range of marketing and administration (M\&A) expenditures. ${ }^{10}$ Budgets for marketing and administration of green pricing programs are a function of several factors: the size of the utility service area; the media markets encompassed within this area; and certainly, not least, the utility's commitment to and goals for the program. The goal of some utilities is only to offer the option of buying green power, so marketing is deemphasized. Figure 1 shows average M\&A expenditures for five different size categories of utilities, based on their eligible customer base. ${ }^{11}$

\footnotetext{
${ }^{10}$ At present, these data sets are among the only, if not the only, aggregated data on marketing costs in the green pricing industry.

${ }^{11}$ In reporting these data, utilities were offered the choice of providing actual expenditure figures or choosing a range within which they spent for $M \& A$, such as 0 to $\$ 10,000$ of M\&A expenditure, $\$ 10,000$ to $\$ 50,000, \$ 50,000$ to $\$ 100,000$, etc. Most programs chose to identify a range only.
} 


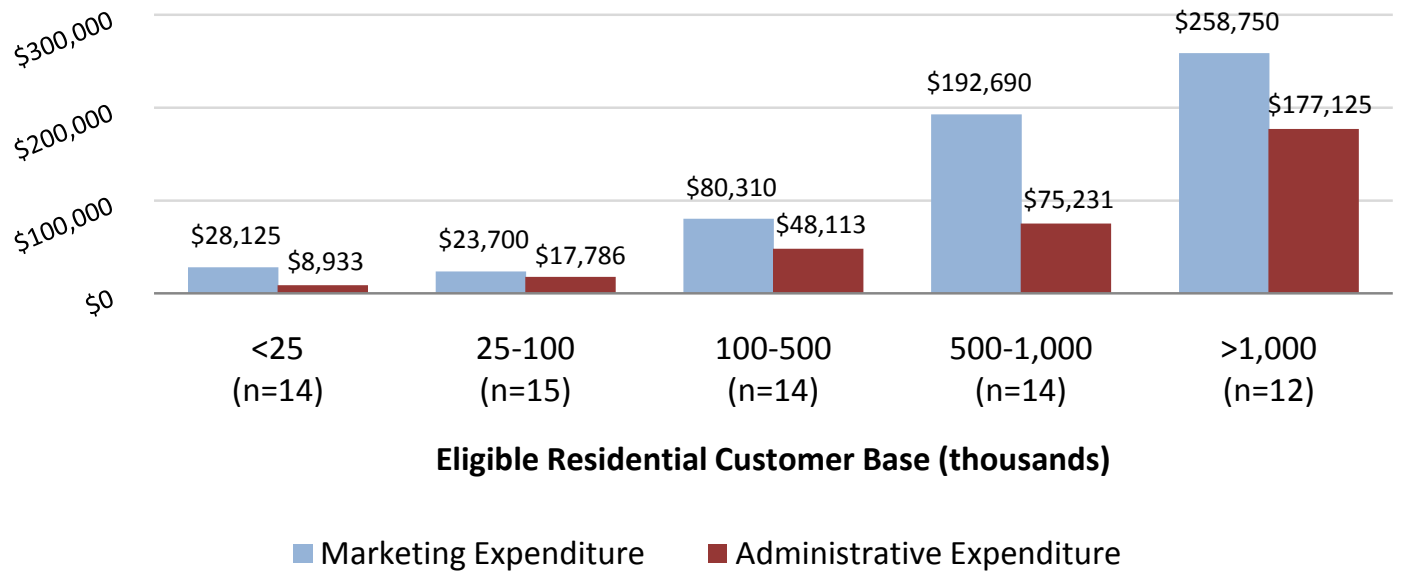

Source: NREL 2009

Figure 1. Average marketing and administrative expenses (gross) in 2008 , by size of eligible customer base

Whether expressed in absolute terms or as a percentage of program revenues (Figure 2), marketing expenditures vary widely among programs. Although it is among the most common metrics, expressing expenditures as a percentage of revenues is somewhat problematic, because it is easy to overlook the fact that a lower expenditure percentage may be as much a function of a relatively high premium and high program revenues (the denominator in the equation) as the marketing expenditure itself (the numerator in the equation). The wide range in marketing budgets supports the notions that the industry lacks clear agreement on benchmarks and that appropriate levels of expenditure depend on the circumstances specific to individual programs.

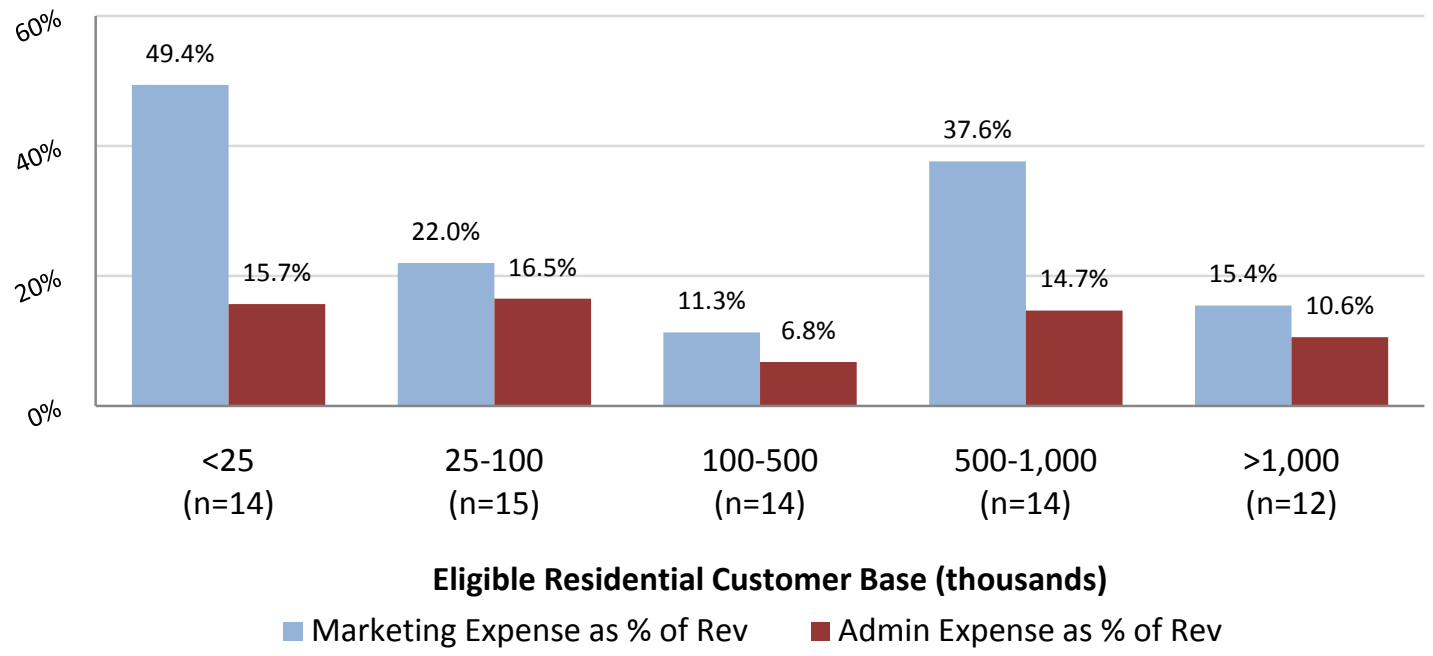

Source: NREL 2009

Figure 2. Median marketing and administrative expenses in 2008 as a percentage of green power revenue 
Another metric that can be used to measure marketing expenditures is gross expenditure divided by the total green power (in $\mathrm{kWh}$ ) delivered. ${ }^{12}$ Figure 3 shows average marketing program expenditures per $\mathrm{kWh}$ of renewable energy sales among utilities of various sizes, from those serving fewer than 25,000 customers to those serving more than 1 million customers. The average marketing expenditure for green pricing programs ranged from $0.08 \phi(8 / 100$ ths of a cent) to $0.18 \notin(18 / 100$ ths of a cent) per $\mathrm{kWh}$ of green power sold. Though all metrics have limitations, this metric has the advantage of integrating program outcomes with marketing expenditure.

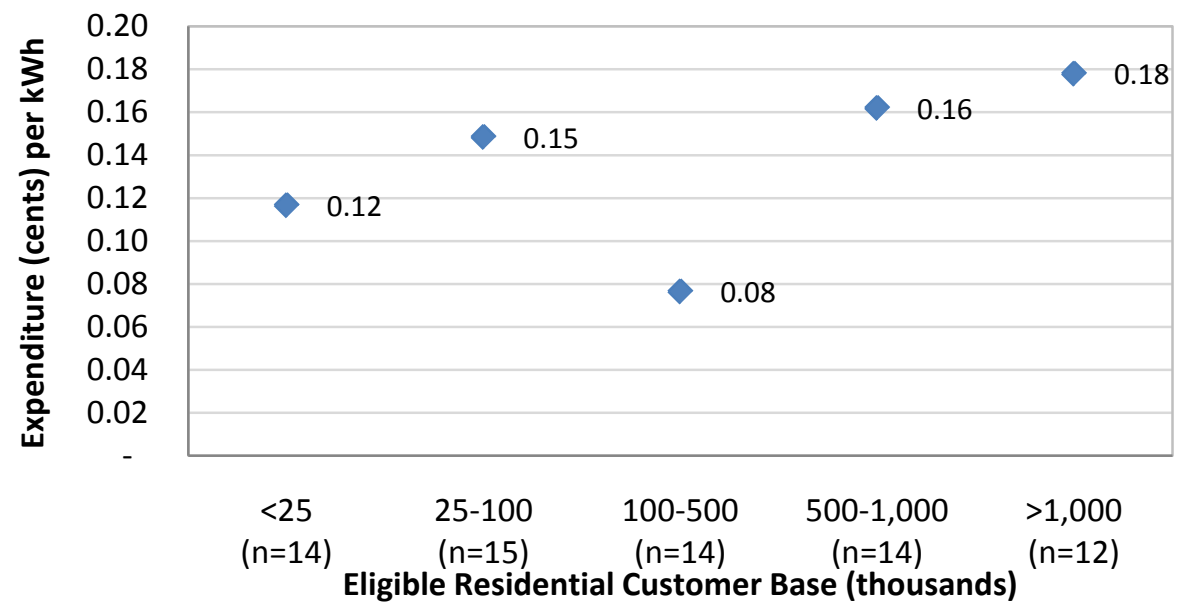

Figure 3. 2008 average marketing expenditure (cents) per kWh of green power sold, by size of utility

By using these data to form conclusions about program expenditures, some caveats should be considered. Programs' data collection methods and proficiency tend to be inconsistent. There is no single set of accounting definitions to which programs adhere. Some programs do not collect these data at all, and some collect but have not reported it to NREL. In addition, there is likely an inherent "survivorship" bias, or tendency for programs to under-report data showing poor results or high acquisition costs. Several programs either have no budgets or rely on broader utility marketing budgets for some or all of their marketing expenditures and/or labor costs. In such cases, these costs are paid for by all ratepayers rather than solely by program participants, resulting in a lower reported expenditure. The recent increased scrutiny on these data suggests improving and standardizing accounting and collection practices.

With this empirical marketing data in mind, we now turn to a discussion of the major criticisms of green pricing marketing expenditures.

\footnotetext{
${ }^{12}$ The virtue of this measurement is that it "levelizes" the data, adjusting for utility size.
} 


\section{Common Criticisms}

In this section, we identify and analyze major areas of concern regarding the marketing and overall performance of green pricing programs. We present the following four common and related criticisms, along with considerations helpful in evaluating their merit:

1. Green pricing programs spend too much on marketing.

2. Marketing expenditures serve private, not public, interests.

3. Green pricing programs do not result in new renewable energy development.

4. Public disclosure is poor and programs are not transparent enough.

In general, market participants have recently become more cognizant of these issues. This paper aims to identify issues for which the market is seeking solutions. Because solutions to many of these issues are generally program-specific in nature and a subject for market participants and regulators, suggestions are made but the evaluation of specific solutions is beyond the scope of this paper.

Common Criticism No. 1: Green Pricing Programs Spend Too Much on Marketing The core criticism highlighted by some industry observers around the country is whether programs simply spend too much on marketing. This question is actually complex, contextual, and multidimensional. Optimal expenditures depend upon the individual program design, the goals of the marketing campaign, and the goals of the regulatory body in approving the program. Some degree of marketing is needed to inform customers that they have the option to participate in green pricing programs; without participants, programs cannot succeed by any measure. But what level of marketing expenditures is appropriate? Have programmatic goals been achieved, and have they been achieved cost effectively? A meaningful response depends upon one's view of the nature of the green power product. Is it in fact a product at all, so that the goal of marketing is a sale, or is it a good cause that benefits society, so that the goal of marketing is public education and support for renewable energy? Or is it both of those things, with the balance between the two depending on the individual program, why it came into being, and what it is trying to accomplish for its constituents?

Below, we discuss these fundamental questions about the nature of the product, along with other aspects necessary for a given program to consider in making its own evaluation about an optimal level of expenditure. We begin with an examination of the relationship between spending and program success, the unique expenditures associated with the first year of a program and the rest of the start-up phase, and the return that should be expected on marketing investments.

\section{Relationship between Marketing Expenditures and High-Performing Programs}

In evaluating the perception that some programs spend too much on marketing, the relationship between spending more and getting more customers to sign up must also be understood. Historically, the top-performing green pricing programs have been among the top spenders on marketing. For example, in 2006 the programs that sold the most renewable energy and garnered the greatest participation generally spent more on marketing, in absolute terms, than other utilities did. Figure 4 shows that the top performers for that year, defined as those that were among the top 10 programs for customer participation, green power sales, or customer participation rate, are overrepresented among utilities spending the most on marketing. 
Figure 4 shows that more than half of programs spending more than $\$ 100,000$ per year on marketing were in the top 10 in at least one category, compared with about $14 \%$ of those spending less than $\$ 100,000$ per year. ${ }^{13}$

Over the years, sales and participation have been concentrated in the hands of a few programs. While the vast majority of programs have struggled to reach $2 \%$ residential penetration in their first five years or more, top programs that tend to spend more on marketing often surpass 5\% in the same period. Industry observers have long noted that stronger performance has been made possible largely with dedicated and effective marketing, with the following additional qualitative factors also playing decisive roles in generating participation (Bird et al. 2008, Bird et al. 2009):

- management support and internal champions within the utility,

- effective program design and implementation,

- product quality and other program benefits,

- the point in time one is studying and the popularity of renewable energy in popular discourse,

- the age of program, and

- a utility customer base pre-disposed in their demographics and buying behavior to support green power, such as residential customer segments that demonstrate environmental concerns or awareness (Friedman 2005, Bird et al. 2008). ${ }^{14}$

\footnotetext{
${ }^{13}$ Although the 2006 result provides some evidence that spending more on marketing is effective for generating sales and participation, data for 2007 and 2008 were inconclusive on this point. It is also important to realize that in two of the three top performing categories (sales and number of participants), large utilities may reach top performer status simply by virtue of their size, which could also account for greater marketing expenditures.

${ }^{14}$ The E Source Green Energy Service identified customer segments in the PRIZM NE customer segmentation system, owned by Claritas Inc., that were more likely than other segments to buy green energy, based on a statistical confidence level of $95 \%$. This analysis was based on a comparison of green pricing participants with nonparticipants. PRIZM NE is a system that categorizes every U.S. household into one of 66 segments based on their age, gender, income, media, purchasing, and other habits. For more information, see Friedman 2005 and Bird et al. 2008. In addition, as noted in Holt and Holt 2004, the overall lack of improvement in participation rates results from a number of factors, including a lack of customer awareness of the green power program ... and varied levels of interest among utilities in marketing and promoting the program.
} 


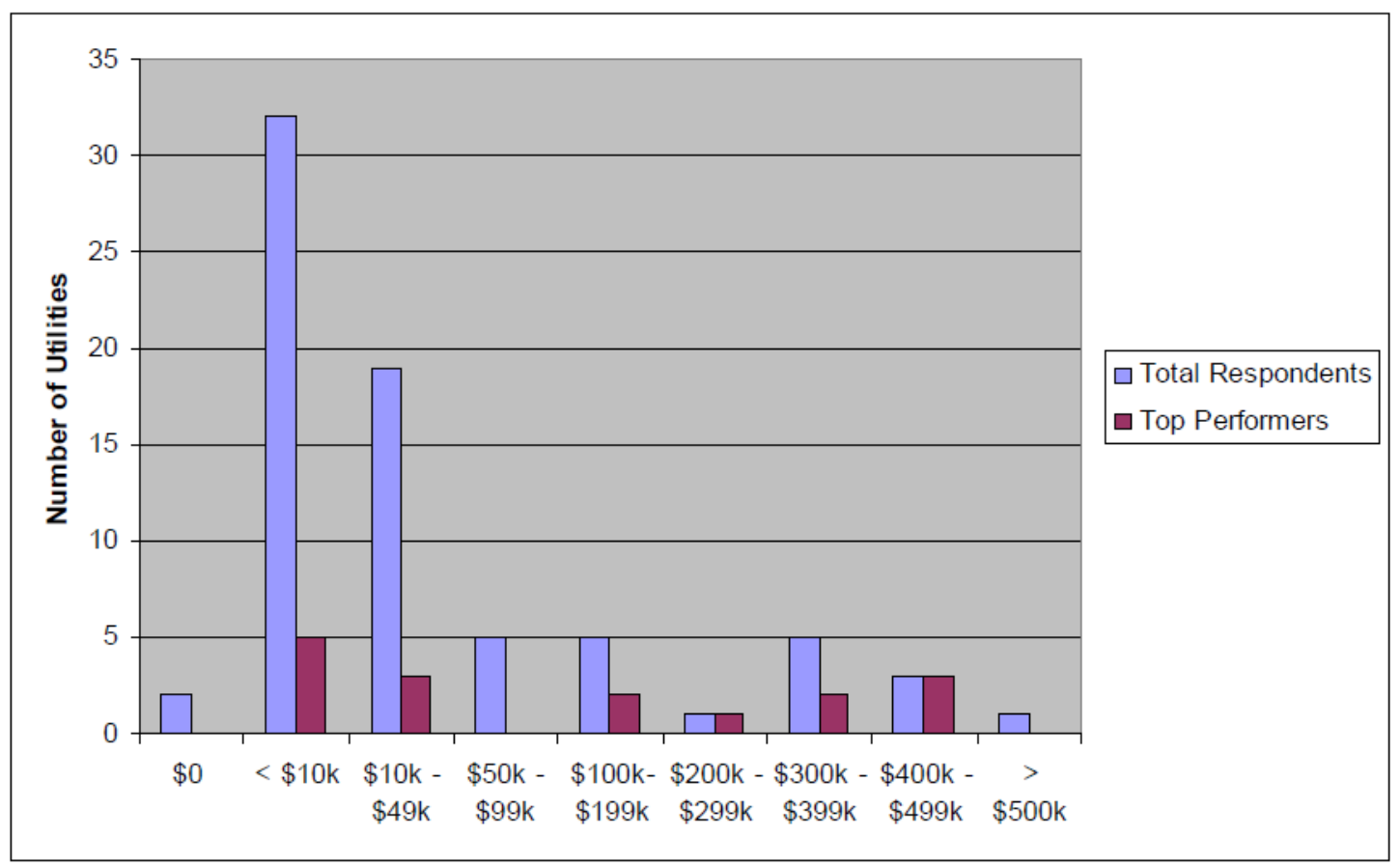

Figure 4. Utility expenditures on marketing, total number of utilities providing data to NREL, compared with top performing utilities providing data for 2006. For that year, more than half of programs spending more than $\$ 100,000$ per year on marketing were in the top 10 in at least one category, compared with about $14 \%$ of those spending less than $\$ 100,000$ per year.

The variables that contribute to participation and growth are numerous. In examining the longitudinal data reported by the same set of programs from 2004-08, there was no discernable correlation that would indicate that marketing expenditures alone are the primary determinant of program growth. In other words, we observed no pattern showing that a program spending more in a given year resulted in more residential sign-ups, or that spending less would result in fewer. The data is insufficient to form firm conclusions, and there were several examples of significant changes in spending from year to the next that was not reflected in the number of sign-ups.

Although a trend or pattern cannot be discerned from reported data, individual examples certainly can. In these, it is difficult if not impossible to separate out the amount that is spent from the decisions and strategies supporting that marketing expenditure. There are several examples of dedicated, sustained marketing efforts yielding sign-ups. In the 1990s, Xcel saw strong small business participation through the support of Western Resource Advocates (then the Land and Water Fund of the Rockies) sustaining an effort to promote the program among that sector. The We Energies program grew significantly in 2005 and 2006. Expenditures increased for 2006, which allowed the program to do three direct mail residential campaigns and one direct mail business campaign, which resulted in an increase of $26 \%$ in residential customers and an increase of $67 \%$ in business customers that year. In 2009, the Puget Sound Energy program is taking a similar trajectory through focused and diverse marketing. ${ }^{15}$

\footnotetext{
${ }^{15}$ In examining percentages of programs in this category of anecdotal examples of marketing paying off, there are more examples among programs marketed in partnership with REC marketers.
} 


\section{Hybrid Nature of Green Power: Charitable Contribution or Product?}

In determining optimal levels for programs to spend on marketing, it is helpful to appreciate the ambiguity in the nature of the green pricing product and premium. Is the premium a payment for a product or a donation supporting a cause? Customers are purchasing a product, in that they are paying for a specific quantity of renewable energy to match their electricity consumption. Yet green pricing programs bear important similarities to charities in two major respects: the view that they do not convey a tangible personal benefit to the consumer ${ }^{16}$ and the messaging used to promote them.

The similarities to charitable organizations are significant in that green pricing programs may well be facing more scrutiny because of those similarities. Companies selling products and services are rarely scrutinized on this basis. More often, marketing is seen as a support to product quality and, at least potentially, the ability to "grow the pie," or sell more product.

In the case of green pricing programs, if more marketing expenditure results in greater demand for renewable energy or in greater program participation, should that reduce the importance of the question of how much was spent on marketing? The answer to that question depends upon green pricing participation being seen as a cause motivated by a public good; charitable organizations' value is evaluated in part on how little they spend on marketing and administration.

Perhaps the most significant basis for the comparison to charities is the fact that few known commercial products, fair-trade coffee and sustainably harvested timber are among them, are sold for profit while bestowing only a public benefit. Sustainably harvested timber is not materially superior to conventionally harvested wood, but confers ecological (public) benefits in the production process (Wiser et al. 2001). However, most products bestowing a public benefit simultaneously provide a perceived personal benefit. For example, organic food is sold for profit, and like green power, its purchase is often motivated by societal values such as reducing reliance on pesticides that can have harmful effects on wildlife. But because the product also bestows a tangible, or perceived, personal health benefit to consumers, we would not conclude that the societal benefit is the driving reason for the purchase.

Some utilities have marketed programs as charitable contributions that are, in some cases, taxdeductible, ${ }^{17}$ but the industry has more typically framed green power conceptually as a product, a quantity of renewable energy that matches all or part of a consumer's electricity usage. By allowing tax deductions in some cases, the Internal Revenue Service has treated the premium as a charitable donation, recognizing the educational purpose of such programs and the public good they provide. Although the donation-based program design has lost favor in recent years, the fact that some programs have been structured as nonprofits underscores the similarity of the product

\footnotetext{
${ }^{16}$ Some green power products offer consumers tangible personal benefits in the form of hedging against future fuel price increases; they might also offer discounts at participating retailers or other types of promotions. See also Wiser et al. 2003.

${ }^{17}$ For example, NC Greenpower, a program that is offered to utility customers throughout North Carolina, offers tax deductions for "contributions" to the green power program. For more information, see http://www.ncgreenpower.org/signup/online_contributions.html.
} 
to a charitable cause. Of the more than 850 U.S. green pricing programs, about $15-20$ call themselves "contribution" programs. ${ }^{18}$

In its peculiar hybrid nature, the green pricing premium could be compared to a donation to public radio. Green pricing program participants "buy" the product for their neighbors, not just for themselves. They pay for an asset that inures to the benefit of all ratepayers and to the utility, in the form of environmental and other benefits. But unlike charities, green power consumers buy a product tied to specific quantities based on the amount of energy they use rather than what they can afford or wish to contribute. And like public radio, marketers work to make a connection in the users mind to specific amounts of consumption to underscore the distinction of charities or cause marketing and the value of the product.

The second factor giving rise to the comparison between voluntary renewable energy programs and charities is the similarity in messaging, with its emphasis on doing the right thing, making a difference, and issuing a call to action for both future generations (the legacy message) and the environment. This ambiguity between for-profit and nonprofit messaging is somewhat unique to the green power industry. Similar to charitable organizations, green pricing programs typically craft so-called "cause marketing" messages that resemble a request for a donation. Typical examples of marketing claims and calls to action in green pricing marketing materials include the following:

- a ...way to support our environment.

- leaving our family a brighter future.

- develop new renewable energy resources.

- make an impact ... on the environment.

Energy-based green pricing programs can be distinguished from charities on the basis of the specific amount of energy delivered to the grid. In charity, the donor gives what they can afford in expectation that the beneficiary will put their contribution to "good use." The efficacy of the charity is judged in part on the portion of the donation spent on the "cause." This ratio is not always known at the time the donation is solicited. In addition, because some companies now use renewable energy to claim emissions reductions, it is important to understand that such claims are made on the basis of a purchase of renewable energy, as distinguished from a donation.

In contrast, an energy-base green pricing program typically offers a firm quantity of renewable energy at a firm price. The price, terms and conditions are disclosed in standardized language in most cases and always in the case of Green-e Energy ${ }^{\mathrm{TM}}$ certified programs. For example, when programs offer a $100 \%$ usage option, if a customer on average uses $1,000 \mathrm{kWh}$ per month and the offered green premium is 1.5 cents per $\mathrm{kWh}$, then the consumer can be confident that their enrollment will result in $1,000 \mathrm{kWh}$ of renewable energy being added to the grid at a cost of $\$ 15$ per month added to their bill. The customer can evaluate whether they perceive the offering to be a good value.

\footnotetext{
${ }^{18}$ For more information, see greenpower.energy.gov.
} 
In the final analysis, it is only in considering the hybrid nature of green power programs that a balanced assessment can be made of whether marketing costs are excessive in specific cases. In fact, one's view of whether programs are businesses or social causes may suggest whether the question makes sense. For those viewing programs through a business lens, it is legitimate to ask whether programs should be judged on the amount they spend on marketing and administration or by the amount of renewable energy they generate. It is often assumed that marketing costs are spent at the expense of product quality. But to the extent that marketing investment grows the participant base and market size, program revenues spent on marketing will not in fact result in less spent on renewable energy. A causal connection between minimizing the size of marketing expenditures in order to improve product quality would not make sense for a typical CEO, running a business for which marketing expense is a given, and its size is commonly considered a matter of business strategy. Similarly, a purchaser of a luxury automobile does not generally concern herself with how the company's international marketing budget contributes to the final sticker price.

Given these conflicting perceptions of green power programs, utilities may reasonably expect that residential consumers will have a right to know the underlying cost structure of green power pricing programs and an interest in minimizing marketing costs. And in some cases, it is not easy for utilities to predict whether the magnitude of marketing expenditures conform to the spirit of the green pricing plan as approved by the regulator-the FPSC had approved the Sunshine Energy program design before cancelling it. In a time of increasing attention on the renewable energy industry and public awareness about renewable energy, several utilities have moved to decrease marketing expenditures.

\section{Costs Unique to the Start-Up Phase}

In evaluating program costs, it is important to consider how marketing and administration costs tend to decline during the life cycle of any new product launch. In this regard, green pricing programs are no exception. Like any business, the start-up phase is a relatively costly investment for which programs sometimes do not see a return for several years.

On the other hand, it can become more costly to attract customers in the later years in the life of a program, after the "low-hanging fruit" - the customers most inclined to sign up - are already enrolled. In this later phase, some programs engage in more expensive marketing tactics, like direct mail or telemarketing. Program managers might do this for a combination of reasons. For example, they might conclude that the less expensive bill inserts or bangtails have accomplished what they can, they could be limited in the number of bill inserts that their program can use because of competition from other utility programs, or they might tailor specific messages to residential customer segments that have been less inclined to participate. As a result, marketing costs could rise again in the later years of a program.

In the start-up phase of a business - which can be a different length of time for different industries - the new business has a disproportionate need to spend money on several cost components that tend to lessen in subsequent years. These include the following:

- Hiring and training staff and call center representatives

- Conducting market research

- Developing a business plan and designing the program 
- Establishing a brand and building product awareness

- Identifying the target market and message

- Building a Web site

- Identifying and purchasing wholesale products

- Developing and creating marketing materials

- Establishing mechanisms for billing and for processing sales.

Generally speaking, the primary job of any marketing campaign is the acquisition and retention of customers. Data reported to NREL suggest that green pricing programs' customer attrition rates tend to be low: utilities reported an average dropout rate of $6.5 \%$ in 2008 ; historically, the average turnover has been below $8 \%$ per year (see Figure 5). ${ }^{19}$

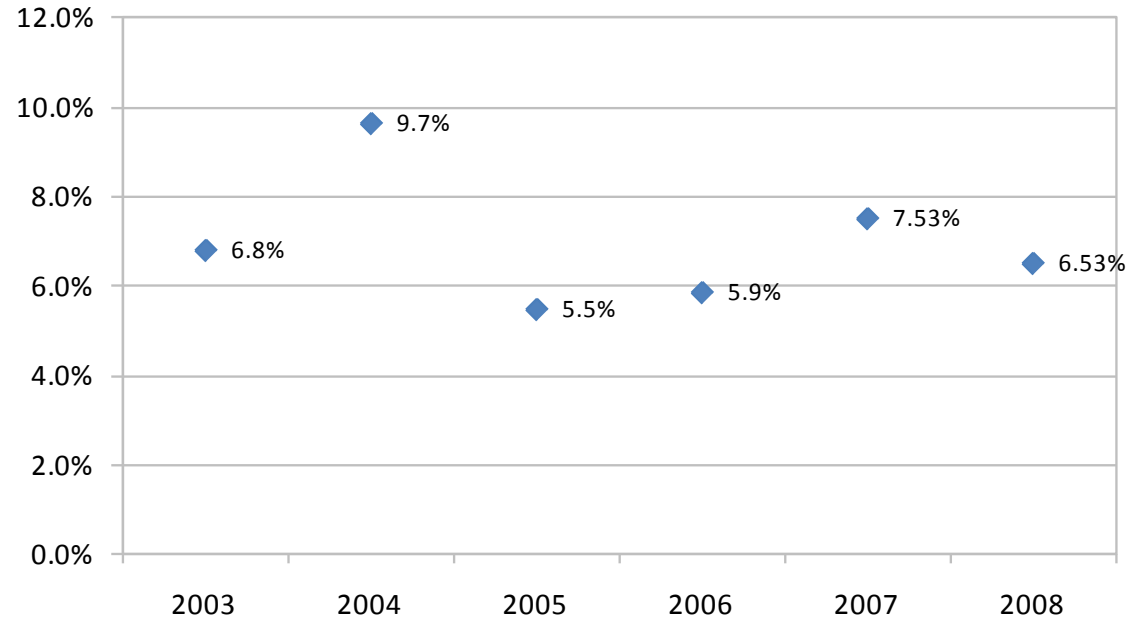

Figure 5. Average dropout rate in voluntary green power programs, 2003-2008

As one would expect of low-turnover businesses, the bulk of green pricing marketing expenditures have been directed toward customer acquisition rather than retention. Low attrition means that the lifetime value of the average individual customer is relatively high. Knowing this, program administrators can spend more on customer acquisition, since they can amortize these costs over the expected lifetime of the customer's participation. The result can be an even greater front-loading of expenditures toward the beginning of the program's life, particularly in the first year. One would therefore expect program implementation expenditures, of which marketing costs are typically the lion's share, to shrink as a percentage of the total after the start-up phase of the program.

The start-up burden comes with an added dimension for new products that are unfamiliar to the public. Over the history of a green pricing program, an administrator faces the dual challenges of eliciting the sale of a novel product and educating the customer base about a complex and often confusing subject. Like most of the other cost burdens, the heaviest burden of basic consumer

\footnotetext{
${ }^{19}$ There is likely inconsistency in the way that billing systems record dropped participants. In most cases, systems would not include participants that change addresses within a service territory, but there are some cases in which such customers are included among dropouts from programs.
} 
product education also belongs in the start-up phase. For example, when the Toyota Prius was first marketed, a new local Toyota dealer would have had to build a brand for itself, even as Toyota was educating the customer on hybrid vehicles. New green pricing programs did not have the benefit of a national manufacturer building public understanding of a new product, and so had this dual obligation during most of the history of the product (at least up until what some consider the "tipping point," if not in program participation, at least insofar as the increase public awareness of and political discourse about renewable energy, in 2007 to the present). Consumers will not buy a product if they do not understand its function or value; so, in the product-launch stage, early market entrants incur expenses that second- or third-generation entrants typically do not. In large measure, hybrid vehicles offered later by other companies will need to establish a brand but without the cost of basic product education.

In theory, green power programs have been in this start-up phase for most of their existence, since median participation levels have remained below $1.5 \%$ of residential customers. If they could build a critical mass of interest and emerge from start-up, they might be able to devote a progressively smaller share of revenues to marketing. The dual perceived burdens of building a brand and educating consumers is particularly acute when participation remains so low.

We examined marketing expenditures across the first three years of a subset of 15 programs. These figures are shown below for the 15 programs that consistently reported marketing expenditures across their first three years of operation. ${ }^{20}$ As shown in the data, regulators and new program managers should expect significant first-year up-front costs. Mean marketing expenditures fell from $\$ 175,318$ to $\$ 62,036$ in the first three years of program operation (Figure 6).

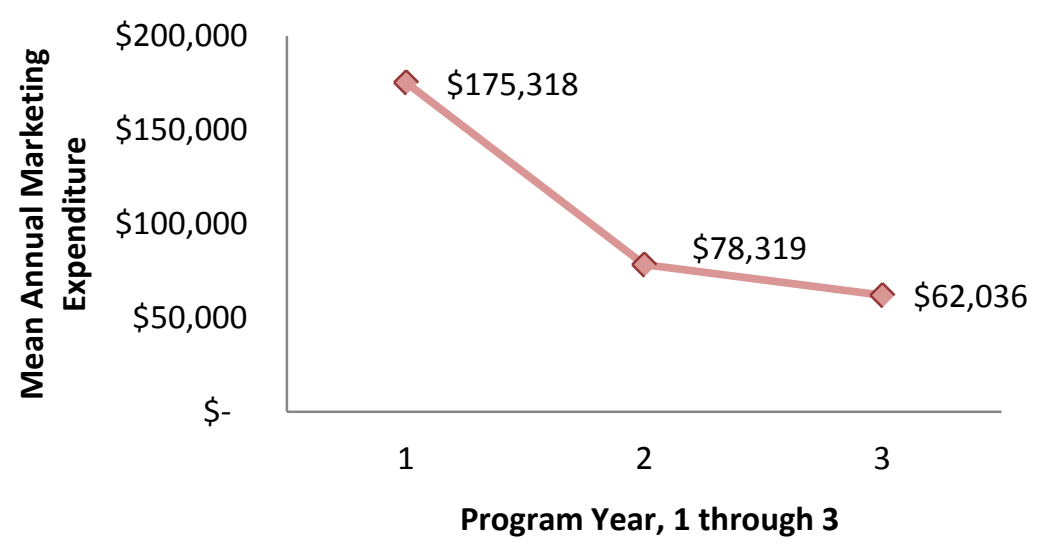

Figure 6. Mean annual marketing expenditure, years 1-3

\footnotetext{
${ }^{20}$ All data as reported to NREL. All 15 programs were launched in 2003, 2004, or 2005. These 15 programs are of widely varying size, serving residential bases between 3,724 and 3,828,275 customers.
} 
These data suggest that green power programs conform to the pattern, found generally across industries, of higher levels of spending during start-up.

\section{Customer Acquisition Costs and Return on Marketing Investment}

In looking at what might be appropriate marketing expenditures, it is important to examine the results programs are getting for their investments. Note that return on marketing investment is not always an easily quantifiable data point. Some of the difficulties in measuring and evaluating marketing expenditures are discussed in the sidebar.

Generally speaking, programs that reach sign-ups more cost effectively have by definition a better return on investment. This, in turn, increases their opportunity to support new renewable energy development faster and with more funds. Even if revenue neutrality or profitability is not a program goal, all programs must sustain themselves economically, and they cannot do so without sign-ups. No business can be expected to sustain itself without investing in communicating its value proposition; in many ways, utility programs are no different.

Programs that are focused on the product or program's economic viability or those required to maintain "revenue neutrality" (the term often used for a program covering its costs via its revenues) will need to scrutinize their return on marketing investment and their customer acquisition cost. They will need to ensure that their marketing efforts are cost effective, and for these programs, cost effectiveness is a metric relevant to the question of whether they are spending too much. A simple example illustrates the point: a program spending $\$ 60$ per new residential customer and charging that participant $\$ 5$ per month will cover that cost after the first year. Since program attrition rates tend to be below $10 \%$ per year, the merit of that $\$ 60$ initial investment is apparent.

\section{Measurement Problems in Marketing Expenditures}

The programmatic marketing and/or administrative component of costs can be expressed in several ways:

- In absolute terms: that is, an annual, or monthly, expenditure

- As a percentage of program revenue

- As a percentage of program costs

- As a per-net-acquired-participant cost, to show the effectiveness of the expenditure at acquiring customers; this is often referred to as "customer acquisition cost," or CAC

- As a per-unit-of-renewable-energy (MWh) cost, to show the effectiveness of the expenditure at selling renewable energy

- As a dollar amount per total utility customers served, to show the marketing budget adjusted for total utility size (as measured by number of utility customers)

Each of these metrics for expressing marketing expenditures has its utility and its limitations. Regulators in both the Indiana and Florida cases examined marketing and administrative costs as a percentage of revenue. However, isolated from the other metrics, expressing marketing and administration costs as a percentage of revenue has limited utility, since programs with higher premiums fare better. Moreover, utilities need only raise their premium to lower their marketing expenses relative to revenues.

As a metric for measuring the effectiveness of marketing spending, CAC eliminates this de facto penalty for keeping premiums low. Therefore, CAC better captures the return on marketing investment and allows a more accurate evaluation of marketing expenditures.

The metric that perhaps best captures these results (for residential customers) is customer acquisition cost or $\mathrm{CAC}$, which is defined as the annual marketing budget divided by the number 
of new residential customers gained in the same period. ${ }^{21}$ Data reported from utilities yields a median estimated customer acquisition cost of $\$ 27$ per net new residential customer in 2008, in comparison to a median CAC of $\$ 30$ in $2007 .{ }^{22}$ Acquisition costs varied by size of utility, and we disaggregated NREL data into five categories by size of eligible residential customer base: fewer than 25,000 customers, 25,000-100,000 customers, 100,000-500,000 customers, 500,000-1 million customers, and greater than 1 million customers. Median estimated 2008 customer acquisition costs are shown in Figure 7.

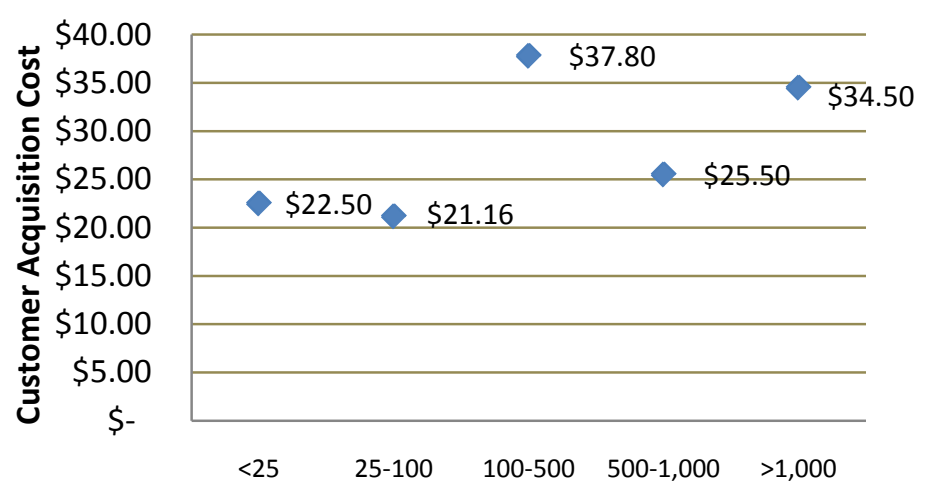

Eligible Residential Customer Base (thousands)

Figure 7. 2008 customer acquisition cost, by customer base size
How do these figures compare with those of other industries? It should be noted that rigorous industry benchmarks are difficult to identify; firms are generally reluctant to disclose customer acquisition costs to avoid disclosing part of their business strategy. Nonetheless, some data are available, albeit from industries that expect higher annual revenue from customers than do green power programs, so the numbers are not directly comparable.

In one example, Jupiter Research estimates that Earthlink spent $\$ 139$ per customer in acquisition costs in 2005.

At the high end, the research firm Gartner estimates that financial services firms spend $\$ 280$ to obtain a new customer (Wreden 2005), and in 2006-2007, cell phone companies were spending an average of \$392 to acquire a new customer, up from \$349 in 2004, according to Bear Stearns (McCall 2006). The same report suggests that acquisition costs of $\$ 300-\$ 400$ per customer were common in the cell phone industry. A report from Pyramid Research suggests that CAC can typically account for up to $30 \%$ of a mobile network operator's expenses (O'Shea 2006). DirecTV estimates that it costs approximately $\$ 550$ to obtain a new customer (O'Shea 2006). Given this cross-industry context, green pricing programs do not appear to be spending an abnormally high amount on marketing for the green power product.

\footnotetext{
${ }^{21}$ Customer acquisition cost is usually used in the context of residential customers, because the lifetime value of those customers tends to be fairly similar among them, unlike nonresidential customers of varying sizes. Customer acquisition costs may also be calculated for individual marketing campaigns, rather than on an annual basis. In general, the metric of customer acquisition costs can be used to compare programs without unduly penalizing programs with low premiums. Another common metric, marketing costs as a percentage of revenue, distorts marketing performance by rewarding programs that charge high premiums and thus have disproportionately large revenue streams.

${ }^{22}$ Of 84 programs providing data to NREL, 48 green power programs provided adequate data to estimate the CAC.
} 


\section{Marketing Expenditures' Role in Supporting Other Utility Programs}

Some utilities report that as perhaps the most significant utility foray into marketing, green pricing has served to provide valuable experience to other utility ancillary programs. For example, Dan Drennan, the green pricing program manager of Public Service of New Mexico, notes that the effectiveness of using direct mail with an enclosed sign-up mechanism in PNM's green pricing program provided a valuable insight to PNM's electronic billing and payment program, which subsequently grew significantly using direct mail as the primary marketing tactic (Drennan 2009).

\section{Common Criticism No. 2: Marketing Expenditures Serve Private, not Public, Interests}

Another common criticism of green pricing programs focuses on the public and private objectives that programs seek through those expenditures. Many programs spend money not only to encourage sign-ups, but also to inform the broader utility customer base about renewable energy and the fact that the utility has made that choice available to them through the establishment of the program. A better understanding of the public and private interests served by program outreach is important to the marketing debate.

History can be illustrative on this point. The first green pricing programs were launched in the late 1990s during the movement toward retail electricity restructuring and its concomitant emphasis on customer choice. Green pricing programs were the first, and remain the only, nonprice-based differentiator for commodity electricity, the only option for a customer to choose electricity not as a commodity but as a product reflecting customer values. Data show that customers are more satisfied with their utility overall when their utility makes a green power option available to them. ${ }^{23}$

Yet from the outset, customers' confusion about the product made consumer education an important explicit outcome sought by green pricing programs. These educational efforts have been supported by some regulators as squarely within the public interest, because of the product's promise as a solution to environmental and other public issues, and because of the link between customer education and increased consumer demand and, potentially at least, new renewable energy development. However, a review of program marketing literature shows that programs generally do not sell participation on the basis of participant dollars going toward public education; rather, new renewable development and environmental improvement make up the value proposition emphasized.

\footnotetext{
${ }^{23}$ In a 2001 E Source survey of customers of utilities offering a voluntary green power option, two questions were asked to test this correlation. The first question was, "Please tell me your OVERALL feeling toward your electric utility. Using a scale of 1 to 10, with 1 meaning you have a 'very unfavorable' feeling, and 10 meaning you have a 'very favorable' feeling, how favorably do you feel about the company that provides your electric service?" A subsequent survey question asked whether customers were aware that their utility offered a green power program or voluntary option. Among customers who did not participate in their utility's voluntary green power program but who did have an aided awareness of the existence of the utility's program, 55\% gave their utility either a 9 or a 10 favorability rating, compared with only $41 \%$ of those who were unaware. This disparity showed some correlation but not causality; i.e., it could not be concluded that customers' awareness of the program was the reason for their high favorability rating.
} 
Some notable green pricing programs' marketing has been supported with ratepayer-funded consumer education budgets approved by those programs' PUCs. Examples include Oklahoma Gas \& Electric and Public Service of New Mexico. Similarly, several state public benefits funds, most notably those in California and in the northeastern United States, have been used to promote public education about green power options. In these examples, marketing cost recovery was assured to the utilities by the regulatory bodies, signaling a clear regulatory intent that consumer education was a kind of end in itself and should not be a risk-taking endeavor in their view. In breaking from the long-standing mandate of least-cost regulation of energy, these regulators deviated from the norm by approving budgets with goals beyond those of saving ratepayers money. Lastly, eight states signaled their view of green pricing options as supporting public interest through their mandating that utilities offer these options. ${ }^{24}$

Around the country, green pricing programs vary considerably with regard to the implicit boundaries between consumer education and marketing, which has added to the debate about the role of marketing in green pricing. Not all programs enjoy the direct support for consumer education from regulatory bodies that the Oklahoma and New Mexico programs do. This is one area that could merit more attention in future conversations between regulators and green power program managers.

Traditionally, green pricing marketing campaigns straddle the realms of marketing and consumer education, since they have the dual objectives of cultivating a strong participant base and educating a very broad cross section of the total customer base. Each of these objectives seeks to promote the demand for renewable energy. To accomplish these objectives, a variety of marketing strategies and tactics are employed. Marketing tactics are situational; some are more suited to the sales function, while others are geared toward the educational function. Some are more cost-effective when used in the start-up phase, like bill inserts and bangtails attached to billing envelopes; others, like direct mail and telemarketing, tend to work best in more mature phases, when the less expensive approaches like bill inserts have already been deployed repeatedly and an assessment is made that they have garnered the vast majority of potential signups already (Friedman 2006).

According to one REC marketing company that partners with utilities to market green pricing programs, a typical 1- to 2-year residential marketing campaign for a utility of 1 million customers might include 3-6 bill inserts to all customers, 150,000 direct mail pieces, 20,000 conversations with customers at events and store fronts, and 20,000 conversations through call center contacts. These efforts carry significant up-front costs, and in green pricing programs involving a REC marketing company, the risk of low sign-up rates is borne wholly or in part by the REC marketer. These tactics are likely to receive greater regulatory support if they are perceived as consumer education.

Another dimension of the consumer education debate is the shift in public awareness that occurred with regard to renewable energy in recent years. Both the Oscar-winning documentary, "An Inconvenient Truth," and the fuel and energy price spikes in recent years helped to generate unprecedented levels of public interest in alternative fuels and electricity. By mid-2009, new renewable energy portfolio standard legislation was under consideration at both the federal and

\footnotetext{
${ }^{24}$ These states include Colorado, Iowa, Minnesota, Montana, New Mexico, Oregon, Vermont, and Washington.
} 
state levels, and nearly one-quarter of the 29 existing state-level renewable portfolio standards (RPS) have been enacted since $2007 .{ }^{25}$ On the whole, awareness of and interest in renewable energy has reached a new level, becoming significantly more prominent in legislative and public discourse in recent years. Large outlays for consumer education for voluntary programs might be harder to justify in light of the media coverage, and the change in public consciousness is a factor that must be considered in evaluating the educational role of marketing dollars.

\section{Common Criticism No. 3: Green Pricing Programs Do Not Result in New RE Development}

Another contentious dimension of the marketing debate is the perceived gap between what consumers believe they are accomplishing and what they are actually accomplishing by voting with their dollars. Marketing materials generally suggest or emphasize the new development being purchased with premiums (Figure 8.) The question concerning an appropriate level of marketing expenditure has arisen in the first place largely because of doubts over product quality, or what consumers are actually buying. This is the question of whether green pricing has led directly to new project development and renewable energy generation capacity. In mainstream national media articles, critics have accused voluntary green pricing programs of not contributing to new renewable development (Elgin and Holden 2008, Elgin 2007).

The issue is sometimes referred to as financial additionality. There are several different types of and tests for additionality, such as regulatory and performance-based. For this report, we will focus on financial additionality as primary, because it is widely and quite reasonably assumed that participants choose to pay extra on their monthly bill because they believe those dollars give rise to new projects, whether or not they have ever heard the technical term additionality. A project is said to be financially additional if a program's premiums are contributing to the financing of a new renewable energy project to the degree that the project would not have been built but for the premiums.

Financial additionality is a difficult standard to meet and, even when met, can be difficult to demonstrate. There are some examples in which marketers claim that project financing was secured substantially as a result of anticipated voluntary revenues (Barcott 2007). ${ }^{26}$ There are many examples of projects supported significantly by voluntary programs: Xcel Energy's Windsource program in Minnesota supports the approximately $50 \mathrm{MW}$ Moraine Wind II project in Pipestone and Murray Counties in Minnesota. In a 2008 Minnesota PUC filing, Xcel estimated that in 2009, 30\% of the Moraine II output would be used for the Windsource program (MOES 2009). Xcel's Windsource participants in New Mexico have purchased all of the output of the 660-kW Texico Wind Ranch ${ }^{\circledR}$ in eastern Curry County, New Mexico, since 2003. NSTAR Green, a green pricing program in Massachusetts, supports the Maple Ridge $30 \mathrm{MW}$ wind farm in upstate New York through a 10-year power purchase agreement (PPA) between NSTAR, the utility that runs the program, and Horizon Wind, the developer.

\footnotetext{
${ }^{25}$ See http://www.dsireusa.org/

${ }^{26}$ The Barcott piece cites a wind farm in Wray, Colorado, as meeting the financial additionality test.
} 


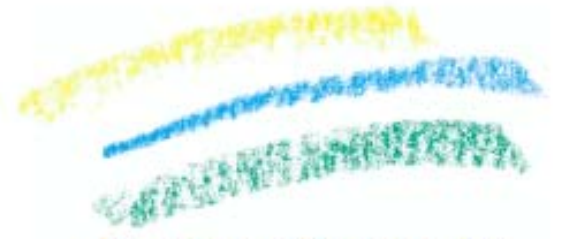

\section{Energy for Tomorrow \\ renewable energy program}

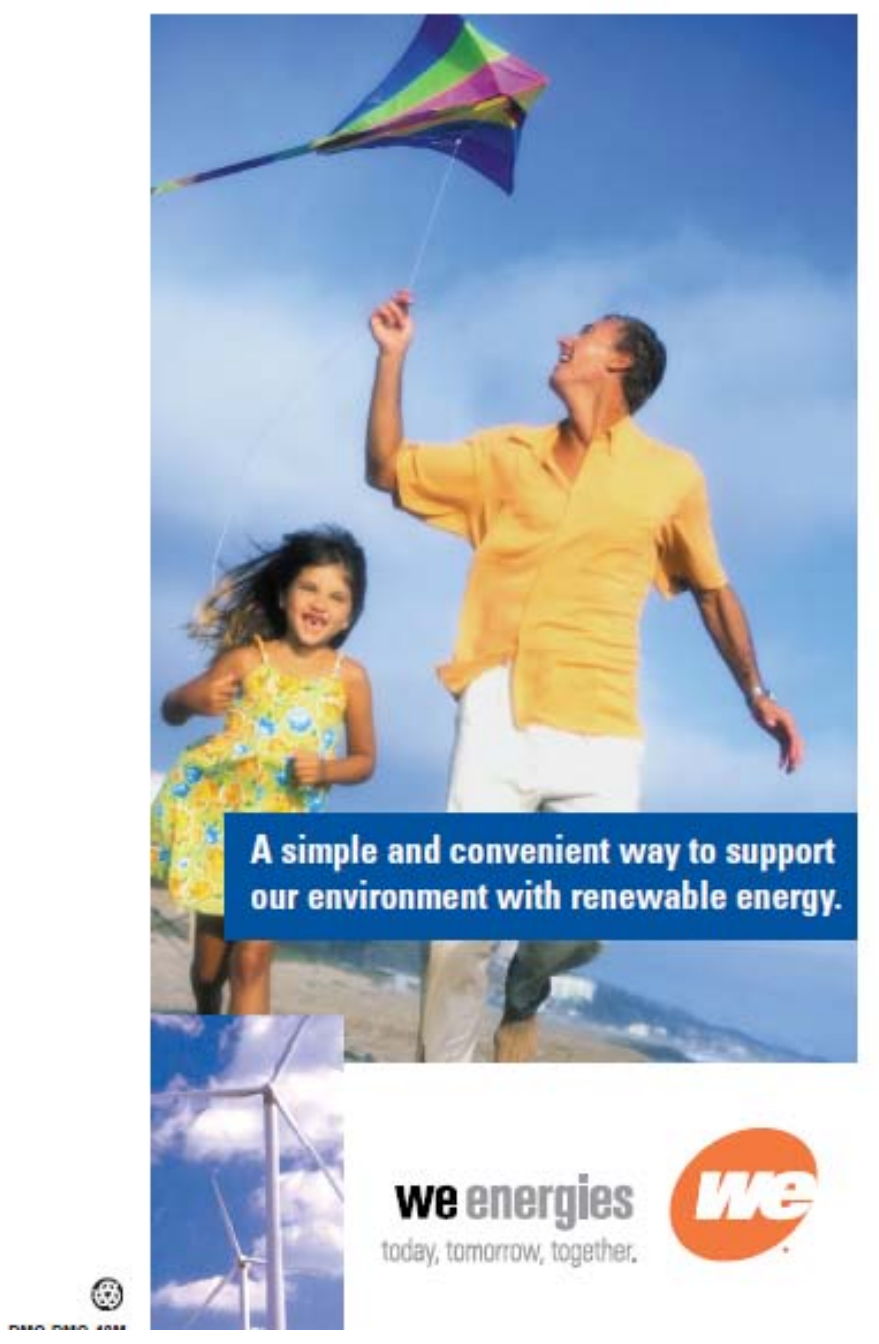

\section{today}

you have the power to make a cleaner world.

\author{
The way we live, work and play impacts our environment \\ and our future. Many of us recycle, plant trees and do \\ other things to keep our world clean - but did you know \\ you can make the world a cleaner place by using \\ renewable energy?
}

Meeting your needs, preserving our world. Our renewable energy sources of electricity such as wind, water and organic materials provide many benefits to you and the environment. They:

- Replace themselves naturally

- Produce lower or no air emissions or solid wastes

- Preserve our limited supply of coal, oil and natural gas

- Improve the environment for future generations

Renewable energy is a sensible approach to energy use!

Together we can do it!

We Energies is committed to generating energy through these renewable sources, and offers you a way to support its production through the Energy for Tomorrow renewable energy program. As one of the largest and most successful programs of its kind in the United States, Energy for Tomorrow is one of only three utility programs to be accredited by the Center for Resource Solutions:

Through our Energy for Tomorrow renewable energy program, you have the power to make a cleaner world!

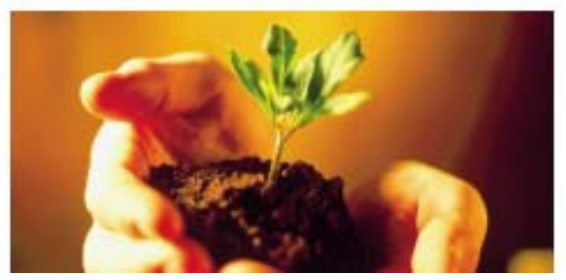

Source: We Energies

Figure 8. Example of green pricing messaging. This portion of a direct mail piece that suggests that the program participation will make a cleaner world typifies marketing messages for green power programs.

The additionality argument is somewhat technical; it is not that programs do not make a difference, but that the difference can be difficult to demonstrate or measure if defined as driving new projects. Also, it is reasonable to assume that participants choose to pay a premium based on the inducement of that definition of making a difference. That is likely the common perception 
among participants - that their money is driving new projects. Yet in practice, it is difficult to assert whether a given new project in the United States would not have gone forward but for program premiums (Gillenwater 2008a, Gillenwater 2008b). ${ }^{27}$ Complicating the issue further is the difficultly in explaining to the public that they are not physically receiving renewable energy when they buy it. ${ }^{28}$

The likelihood of financial additionality is increased if green power programs use participant revenues to enter into long-term contracts, generally 10 years in term length or more, to purchase electricity and/or RECs from renewable energy facilities. From the perspective of developers, long-term contracts, which ensure steady revenue, promote more favorable project financing terms. From the perspective of green power programs, however, there is risk in such long-term forward contracting, because the level of participation is difficult to predict and because consumers typically make only month-to-month or one-year commitments to participate. This demand risk can serve to limit both the scale and the duration of investment in renewable energy. Green power programs deal with this risk in different ways around the country, but details are sparse since the specifics and duration of power contracts are largely undisclosed, under cover of contract. In some cases, programs that enter into long-term PPAs make a determination that ratepayers will at least partly support the purchase, or can, should participant premiums be insufficient. Other utilities are prohibited from passing excess costs on to ratepayers. This tension between the short-term commitments of green power consumers and long-term contracts desired by facilities is a persistent dilemma for utilities attempting to use voluntary premiums to support projects.

There are other mechanisms, however, by which the voluntary market can support renewable energy development. Commonly, programs will buy energy from small-scale producers in the community, for example, paying consumers $10 \phi-25 \phi / \mathrm{kWh}$ for PV system output. In addition, many programs keep premiums in reserve and use these funds to support new project development when a sufficient amount has been collected. And many in the green pricing industry argue that REC demand in the voluntary market puts a ceiling on the available REC supply in compliance markets, thus boosting price levels and supporting larger revenue streams for additional projects. At least one green pricing program administrator has indicated that the presence of a voluntary REC revenue stream encouraged the utility to sign longer power purchase agreements with project owners. As mentioned earlier, longer PPAs support better project financing terms for developers.

On the question of additionality, some use the analogy of organic apple farms. That is, buying an organic apple does not directly cause a tree to be planted or a pesticide-free farm to come into

\footnotetext{
${ }^{27}$ The actual revenue stream is highly dependent upon the region, the presence of an RPS, and the nature of the contract.

${ }^{28}$ The National Association of Attorneys General issued in 1999 Environmental Marketing Guidelines for Electricity Guidelines, "The Attorneys General recognize that it is physically impossible to determine the sources of the electrons used by any given consumer. Thus, when a consumer chooses a particular electricity product based on the environmental attributes associated with how and where that power was generated, what s/he is actually doing is financially supporting the chosen generation source, not buying the precise energy generated by that source. The Attorneys General believe that such financial support is consistent with what consumers who prefer a certain type of generation for environmental reasons would seek to do- that is, direct the flow of their payments for electricity toward preferred generation sources."
} 
being; those decisions must be made well before a purchase, and no one asks whether their purchase caused a new tree to be planted. Yet some trees were planted with a forward-looking expectation of a future market for organic apples. ${ }^{29}$ Similarly, the voluntary market is a source of ongoing revenue for renewable energy generators, and, even absent long-term power purchase agreements, supports their bottom line.

Evidence does not suggest that marketing has a zero-sum relationship with additionality. It is not clear whether more renewable capacity would be built if green power programs were more lightly advertised. Certainly, economies of scale and the ability of the utility to enter into longterm wholesale contracts are improved with rates of participation larger than the national average. Whether the nuances of these competing perspectives should be better explained to green pricing participants is directly relevant to the marketing cost debate. This leads us to the debate over program transparency.

\section{Common Criticism No. 4: Programs Are Not Sufficiently Transparent}

One of the common criticisms related to marketing expenditures is the sense that the programs are not clear in their communications about what they are doing and how they are spending program premiums. Transparency and additionality are integrally related: the call for greater transparency is based in turn on the widely held perception that program participants expect that their purchase is contributing to new development, and the difficulty market players have in actually demonstrating that it has. In addition, consumers may expect that their premium dollars will not be spent on advertising.

In some cases, consumers must go to a utility's Web site to search for the specific projects the program supports; in other cases, the information is not available. Besides this occasional lack of project transparency, there is a second type of transparency some advocates seek: disclosure of the program budget and, specifically, marketing and administration expenditures relative to product expenditures, or budgetary transparency (CCAP 1998).

In many instances, requiring such transparency is difficult or impossible. Yet, for the most part, PUCs and/or attorneys general and consumer watchdog groups have not played an active role. Given the recent criticisms, there is an opportunity for better communication, transparency, and disclosure to regulatory decision-makers in regard to budgets; and to the public in regard to projects. Consumers and stakeholders would benefit from knowing more about projects supported by, and benefits inured from, green pricing programs, since they are the first foray into non cost-based energy choice in the United States.

The Green-e Energy ${ }^{\mathrm{TM}}$ program, which has become the leading certification standard for renewable energy transactions in the United States, ${ }^{30}$ does require a certain level of product disclosure for renewable energy sales, including renewable resource mix, geographic location of generation, purchase size, and default electricity mix (for sellers of renewable electricity). Green-e Energy ${ }^{\mathrm{TM}}$ does not require public disclosure of marketing costs involved in offering certified sales, as it predominantly works with privately held companies that are not regulated by

\footnotetext{
${ }^{29}$ The apple example is taken from various public presentations of Rob Harmon of the Bonneville Environmental Foundation. See also http://www.pnwlocalnews.com/vashon/vib/news/30991554.html

${ }^{30}$ See http://www.green-e.org/.
} 
a body such as a PUC. For similar reasons Green-e Energy ${ }^{\mathrm{TM}}$ does not require that the specific renewable projects generating RECs sold in certified transactions be disclosed. ${ }^{31}$ This highlights the issue of the desirability and willingness of non-utility and non-regulated sellers to provide budgetary and project transparency even if PUCs were to try to require such disclosure. These issues deserve more study.

The issue of transparency can be more problematic in the case of private third-party marketing companies partnering with utilities in the administration of green pricing programs. A growing but still small portion of green pricing programs are managed by third-party REC marketing companies (Bird et al. 2009). ${ }^{32}$ Privately held companies could be at a competitive disadvantage by requiring such disclosure; in some cases, there may also be legal protections against compelling disclosure, depending on the reasons for which it is sought. Programs managed by REC marketers are represented in a higher percentage

Often, REC marketing firms have a different profit imperative compared with independent utility programs not run in partnership with REC marketing companies. REC marketers also present regulators a unique set of challenges because of their regulatory status. At a utility, the rate of investment return is generally fixed on a kilowatt-hour basis. Green pricing programs are often not designed to generate profit, and in some cases, regulators have determined that ancillary utility programs like green pricing should not be profitable. Yet in the case of programs that utilities outsource to REC marketing companies, those companies are expected to return a profit to owners. The introduction of such close partnerships with unregulated REC marketers in regulated markets has given rise to questions among regulators and consumer advocates seeking to ensure that participant interests are protected.

It is perhaps easy to underestimate cost factors for REC marketing companies and assume they are earning larger gross margins than they are. Specifically, REC marketers take on REC price risks. These can be significant, given the volatility of REC markets that are subject to significant policy and market uncertainty. This is especially pertinent when rules set by the regulatory body constrain REC procurement to the service region of the utility, leading to generally higher REC price levels than those on the national market. REC prices vary considerably by region, and in such cases REC marketers are sometimes subject to significant wholesale premiums and the risk of higher prices if a state in which a REC marketer is partnering with a utility introduces a new RPS policy.

There are other forward risks surrounding REC regulation, supply, and price. Most power providers and utilities do not sell RECs on a forward basis in order to protect themselves against regulatory changes; thus, REC marketers typically work directly with developers with projects under construction and in the pipeline, allowing marketers to secure stable supply and provide long-term, meaningful support to a new facility (which addresses some additionality concerns).. Additionally, the fact that REC marketers do not know with certainty the number of RECs that they will be obligated to purchase across the term of their contract adds to supply risk. And the

\footnotetext{
${ }^{31}$ See http://www.green-e.org/docs/energy/Appendix_B-National_Code_of_Conduct_Cust_Disclosure.doc Accessed July 22, 2009.

${ }^{32}$ It should be noted that, overall, those programs tend to perform well as measured in their representation among top performing programs in NREL top ten lists.
} 
swiftly evolving regulatory framework, which could, among other things, raise RPS standards or redraw the boundaries of what classifies as new development, could create additional risks for GP programs. For these reasons, green power providers typically set the green power premium above the cost of RECs to insulate themselves and their REC marketing partners from financial risk. These premiums above the wholesale cost of green power, while not uncommon in the business world, have been a source of confusion for regulators.

The Sunshine Energy program was run primarily by third-party marketer Green Mountain Energy Company in partnership with the utility. In the FPSC proceeding, GME likened its marketing expenditures and other operational decisions to those of any other private supplier to the regulated FPL utility, asserting that GME was protected in its business decisions by freedom of contract as long as the terms of the agreement under which they operated the program were met. ${ }^{33}$ GME argued that the company had honored those terms. ${ }^{34}$ In sum, regulators who may be interested in budgetary transparency should engage in those discussions early in the process of planning a program, particularly where the program is being run by a REC marketer.

\footnotetext{
${ }^{33}$ Although GME did not make an explicit constitutional argument in the proceeding, Article I, Section 10 of the U.S. Constitution states: "No State shall ...pass any...Law impairing the Obligation of Contracts...."

${ }^{34}$ Although they questioned why they should be obligated to a higher degree of transparency than any other FPL contractor, GME voluntarily agreed to a comprehensive review of program finances by Florida Public Service Commission Audit Staff at the company's headquarters. The company also issued its own audit discussion paper and publicly released detailed financial data related to the program.
} 


\section{Conclusions}

Utility green pricing programs function within a complex matrix of overlapping regulatory, financial, environmental, and legal issues. Regulators and program managers will continue to be challenged to ensure market integrity and engage more with one another on program design. An effective program offers a high-quality product that places a premium on the public interest in energy choice and green pricing participants' interest in new renewable energy development.

In light of recent criticisms, programs should prioritize the provision of thorough consumer information in multiple forms, including complete explanations of RECs, how renewable energy is developed and delivered, and how participant funds are spent. An effective collaboration among utilities, regulators, advocates and, in some cases, REC marketing companies, also requires an understanding of cost components that make a program successful. REC marketers have brought a unique set of capabilities to programs and, for the most part, have been highly successful in their utility partnerships.

Where feasible, PUCs should consider the desirability of greater market, project, and, in some cases, budgetary transparency — or at least improving standards in budgetary tracking - to support larger and more accurate data sets and the ability of programs to learn from one another to improve results. Improved program transparency and regular communication with regulatory authorities may promote better understanding of the relationship of marketing activity to program participation and the resulting investment in renewable energy. As has been discussed, PUCs are limited in their ability to require transparency of private companies administering programs in partnership with utilities.

Improved transparency should start with better information to program participants about what projects their premiums support. Better data about expenditures will help regulatory commissions better understand the complexities of the industry, such as the cost risks associated with REC markets, for which price volatility has been significant in certain U.S. regions. Regulators should not merely gather more information about program budgets; they should evaluate marketing expenditures in light of the full range of their purposes and benefits.

The industry, too, could benefit by improving the consistency of these program data-gathering practices, and standardizing the use of metrics such as those discussed in this paper to assess program effectiveness and value. More work is needed in supporting program data gathering practices that will aid regulators in better evaluating the effectiveness of voluntary green pricing programs. Regulators should consider whether they should require better project disclosure and help make available to the public information on projects supporting green pricing programs. In the face of increased scrutiny, it makes sense for utilities and regulators to pro-actively participate in design and budgetary decision-making and continuously test the effectiveness of marketing expenditures in creating demand.

Green pricing program managers and regulators share a common interest in increasing the demand for renewable energy as well as in bridging the gap between the price of renewable energy and that of traditional sources. Both of these objectives have relied on both the marketing and supply of renewable energy through green pricing programs. To ensure the integrity of the 
market, program managers and regulators should carefully measure and study the way that participant dollars are being spent on marketing and product. While there may be no strict rules dictating optimal marketing expenditures, it is clear that marketing and consumer educationcarefully monitored and understood - have an important role to play in the evolving green power market. 


\section{References}

Barbose, G. (2009). Lawrence Berkeley National Laboratory, data provided via e-mail communication, May 21, 2008.

Barcott, B. (2007). "Green Tags: Making Sense of the REC Age," World Watch. July 1, 2007. http://www.accessmylibrary.com/coms2/summary 0286-31844518 ITM.

Bird, L.; Kaiser, M. (2007). Trends in Utility Green Pricing Programs (2006), NREL/TP-67042287. Golden, CO: National Renewable Energy Laboratory, October. http://apps3.eere.energy.gov/greenpower/pdfs/42287.pdf

Bird, L., Kreycik, C., and Friedman, B. (2009). Green Power Marketing in the United States: A Status Report (2008 Data). September 2009.

Bird, L., Kreycik, C. and Friedman, B. (2008). Green Power Marketing in the United States: A Status Report (Eleventh Edition), NREL/TP-6A2-44094. Golden, CO: National Renewable Energy Laboratory, October. http://www.nrel.gov/docs/fy09osti/44094.pdf

Bird, L.; Swezey, B.; Aabakken, J. (2004). Utility Green Pricing Programs: Design, Implementation, and Consumer Response, NREL/TP-620-35618. Golden CO: National Renewable Energy Laboratory, February. http://apps3.eere.energy.gov/greenpower/resources/pdfs/nrel_35618.pdf

Center for Clean Air Policy (CCAP). (1998). Disclosure in the Electricity Marketplace: A Policy Handbook for States. Washington, DC, 1998.

Center for Resource Solutions (CRS). (2008). "Green-e Energy" http://www.greene.org/docs/Green-e \%20Energy \%201-pager.pdf.

Drennan, D. (2009). Public Service of New Mexico, personal communication, August 18, 2009.

Elgin, B.; Holden, D. (2008). "Green Power: Buyer Beware," Business Week, September 18, 2008. http://www.businessweek.com/print/magazine/content/08 39/b4101068119568.htm

Elgin, B. (2007). "Little Green Lies," Business Week. October 29, 2007. http://www.businessweek.com/magazine/content/07_44/b4056001.htm

Florida Public Service Commission (FPSC) (2008). "Review of Florida Power and Light Company's Sunshine Energy Program.” Docket No. 070626-EI. June 23, 2008. http://www.floridapsc.com/agendas/archive/080701cc/08070111.pdf

Friedman, B. (2006). "The Unsung Bill Insert: What Can Green Pricing Programs Expect from This Stalwart?” E Source, February 2006. http://www.esource.com/

Friedman, B. (2005). "Dear Customer: Using a Simple Letter to Generate Green Signups." E Source. July 2005. http://www.esource.com/ 
Friedman, B. (2004). "Making Renewable Energy Print Materials Work: The Customers and Experts Speak.” E Source. December 2004. http://www.esource.com/

Friedman, B. (2002). “Market Research Survey II: Finding Green Energy Buyers.” E Source. July 2002. http://www.esource.com/

Gillenwater, M. (2008a). "Redefining RECs (Part 1): Untangling attributes and offsets," Energy Policy, Volume 36, Issue 6, June 2008, Pages 2109-2119. doi:10.1016/j.enpol.2008.02.036

Gillenwater, M. (2008b). "Redefining RECs (Part 2): Untangling certificates and emission markets," Energy Policy, Volume 36, Issue 6, June 2008, Pages 2120-2129.

doi:10.1016/j.enpol.2008.02.019

Hanson, C.; Van Son, V. (2003). Renewable Energy Certificates: An Attractive Means For Corporate Customers To Purchase Renewable Energy. Washington, DC: World Resources Institute, September. http://pdf.wri.org/gpmdg_corporate guide_05.pdf

Holt, E.A.; Holt, M. (2004). Green Pricing Resource Guide (2nd Edition), Ed Holt \& Associates, Inc., Harpswell, Maine. Prepared for the American Wind Energy Association, Washington DC, September. http://www.awea.org/greenpower/greenPricingResourceGuide040726.pdf

Holt, E.A.; Bird, L. (2005). Emerging Markets for Renewable Energy Certificates: Opportunities and Challenges, NREL/TP-620-37388. Golden, CO: National Renewable Energy Laboratory, January. http://apps3.eere.energy.gov/greenpower/resources/pdfs/37388.pdf

McCall, M. (2006). "Balance Swings to Customer Retention,” WirelessWeek, January 15, 2006. http://www.wirelessweek.com/article.aspx?id=95900 Accessed June 2, 2009.

Minnesota Office of Energy Security (MOES). (2009). "Northern States Power Company d/b/a Xcel Energy's Petition for Approval of a Power Purchase Agreement with Moraine Win II, LLC.” Docket No. E002/M-08-1487. March 23, 2009.

https://www.edockets.state.mn.us/EFiling/edockets/searchDocuments.do?method=showPoup\&d ocumentId $=\{$ CF7BDDBB-95E1-4ECC-9AE3-9DFB1159EA12 $\} \&$ documentTitle $=5829065$

O'Shea, D. (2006). The Brand vs. The Bottom Line. April 3, 2006. Telephony Online. http://telephonyonline.com/mag/telecom_brand_vs_bottom/ Accessed June 2, 2009.

Wiser, R. (2003). Using Contingent Valuation to Explore Willingness to Pay for Renewable Energy: A Comparison of Collective and Voluntary Payment Vehicles. LBNL-53239. Berkeley, California: Lawrence Berkeley National Laboratory, August 2003.

http://eetd.lbl.gov/EA/EMS/reports/53239.pdf

Wiser, R.; Bolinger, M.; Holt, E.; Swezey, B. (2001). Forecasting the Growth of Green Power Markets in the United States. 74 pp.; NREL Report No. TP-620-30101; LBNL-48611. http://apps3.eere.energy.gov/greenpower/resources/pdfs/30101.pdf

Wreden, N. (2005). "ProfitBrand: How to Increase the Profitability, Accountability and Sustainability of Brands.” United Kingdom: Kogan Page, 2005; p. 26. 


\section{Appendix. Sample Green Pricing Program Marketing Materials}

\section{IIII PACIFIC POWER}

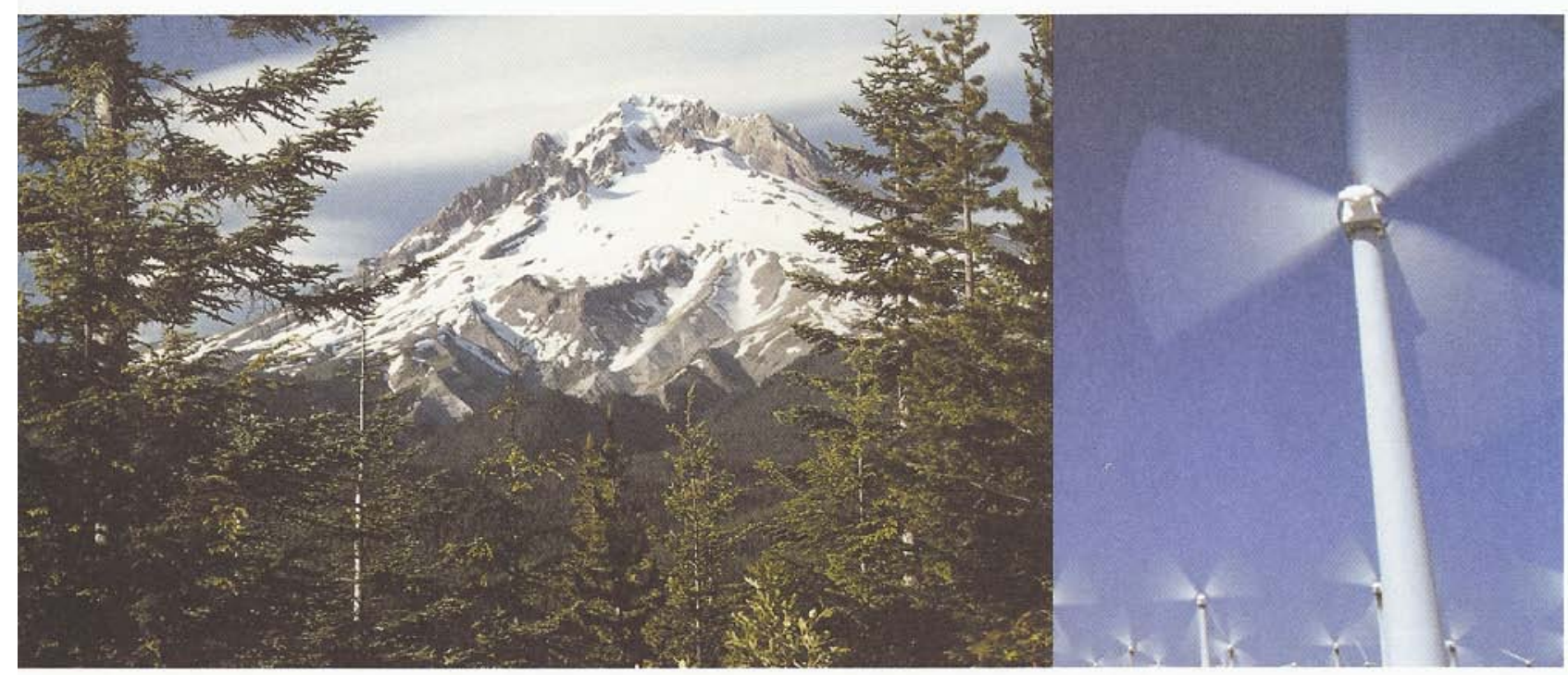

Help keep Oregon clean.

Choose cleaner electricity.

Figure A-1. A portion of a sample marketing piece from the Pacific Power green pricing program run in partnership with GME, a REC marketing company. 




Figure A-2. A portion of a sample marketing piece from the Sacramento Municipal Utility District green pricing program offered in Sacramento, California. 


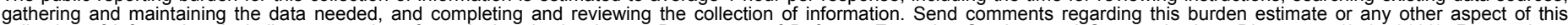

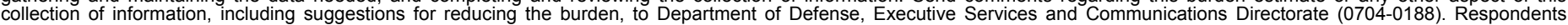

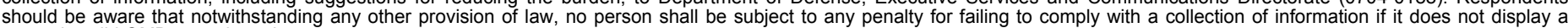

should be aware that notwithstanding

PLEASE DO NOT RETURN YOUR FORM TO THE ABOVE ORGANIZATION.
1. REPORT DATE (DD-MM-YYYY) September 2009
4. TITLE AND SUBTITLE
Green Pricing Program Marketing Expenditures: Finding the Right Balance

6. AUTHOR(S)

B. Friedman and M. Miller
3. DATES COVERED (From - To)

5a. CONTRACT NUMBER

DE-AC36-08-GO28308

5b. GRANT NUMBER 5d. PROJECT NUMBER

NREL/TP-6A2-46449

5e. TASK NUMBER

SAO9.3003

5f. WORK UNIT NUMBER
7. PERFORMING ORGANIZATION NAME(S) AND ADDRESS(ES)

National Renewable Energy Laboratory

1617 Cole Blvd.

Golden, CO 80401-3393

9. SPONSORING/MONITORING AGENCY NAME(S) AND ADDRESS(ES)
8. PERFORMING ORGANIZATION REPORT NUMBER

NREL/TP-6A2-46449

10. SPONSOR/MONITOR'S ACRONYM(S) NREL

11. SPONSORING/MONITORING AGENCY REPORT NUMBER

\section{DISTRIBUTION AVAILABILITY STATEMENT}

National Technical Information Service

U.S. Department of Commerce

5285 Port Royal Road

Springfield, VA 22161

\section{SUPPLEMENTARY NOTES}

\section{ABSTRACT (Maximum 200 Words)}

In practice, it is difficult to determine the optimal amount to spend on marketing and administering a green pricing program. Budgets for marketing and administration of green pricing programs are a function of several factors: the region of the country; the size of the utility service area; the customer base and media markets encompassed within that service area; the point or stage in the lifespan of the program; and certainly, not least, the utility's commitment to and goals for the program. All of these factors vary significantly among programs. This report presents data on programs that have funded both marketing and program administration. The National Renewable Energy Laboratory (NREL) gathers the data annually from utility green pricing program managers. Programs reporting data to NREL spent a median of $18.8 \%$ of program revenues on marketing their programs in 2008 and $16.6 \%$ in 2007 . The smallest utilities (those with less than 25,000 in their eligible customer base) spent $49 \%$ of revenues on marketing, significantly more than the overall median. This report addresses the role of renewable energy credit (REC) marketers and start-up costs-and the role of marketing, generally, in achieving program objectives, including expansion of renewable energy.

\section{SUBJECT TERMS}

NREL; Barry Friedman; Mackay Miller; renewable energy certificates; RECs; energy consumers; electricity; green power marketing; green pricing; renewable energy; electricity markets

\begin{tabular}{|l|l|l|l|l|}
\hline $\begin{array}{l}\text { 16. SECURITY CLASSIFICATION OF: } \\
\begin{array}{l}\text { a. REPORT } \\
\text { Unclassified }\end{array}\end{array}$ & $\begin{array}{c}\text { b. ABSTRACT } \\
\text { Unclassified }\end{array}$ & $\begin{array}{c}\text { c. THIS PAGE } \\
\text { Unclassified }\end{array}$ & $\begin{array}{c}\text { OF ABSTRACT } \\
\text { UL }\end{array}$ & $\begin{array}{c}\text { 18. NUMBER } \\
\text { OF PAGES }\end{array}$ \\
\end{tabular}

19a. NAME OF RESPONSIBLE PERSON

19b. TELEPHONE NUMBER (Include area code) 